\title{
Performance augmentation of continuous miner based system in India: a reliability based approach
}

\begin{abstract}
A Continuous Miner (CM) is a globally competitive machine, capable of boosting the production of underground mines, which is imperative for future production growth. However, the geological factors and other mining parameters of all underground mines do not always support the best performance from the equipment. In this article, the effects of mining parameters like pillar size, gradient, number of headings and equipment fleet on CM-based production system have been observed and a forecast regarding trend analysis has been done. Furthermore, this study enlightens the effects of breakdowns of CM and its allied equipment; the breakdown times for CM and its related equipment are quantified collectively. The percentages regarding the reliability and probability of these types of failures have been considered within the scope of this paper. Corresponding study shows that conveyor breakdown affects the system productivity the most and other failures affecting the production significantly are electrical failure, shuttle car breakdown, hydraulic breakdown, gathering problems, cutter breakdown and traction breakdown. The reliability analysis of each group of components will function as a forecast of the maintenance schedule and inspection frequency of different components in order to decrease failures and increase available time.
\end{abstract}

Key words: continuous miner, pillar size, number of headings, reliability, percentage of failure

\section{INTRODUCTION}

Coal reserves near the surface are nearing exhaustion due to the higher exploitation rate, tending a necessity to produce coal from deeper seams in the near future. Until now, underground mining has been the only economic technique for producing coal from reserves at greater depths from the Earth's crust. India is one of the top-five coal producers in the world, with a production of 639.23 MT of coal in 2015-2016 [1]; though, it is far away from being able to be an effective exporter or even meet its own indigenous demand. This indigenous demand is expected to increase to 1373 MT by 2021-2022 [2]. Therefore, India has planned to increase total coal production to at least $1 \mathrm{BT}$ by 2020 [3]. This plan necessitates the exercise of underground mining to exploit the deeper seams of the Earth's crust.
In India, most of the underground mines operate with the Bord and Pillar method (a variety of room and pillar) with conventional drilling, charging and blasting for coal production and SDL or LHD for loading. Few projects of the major coal producing public sector company of the country are already working with Continuous Miner (CM) and are further planning to introduce new CM-based projects, as CMs are globally accepted machines for their high performance in underground mining (Fig. 1). The compatibility of $\mathrm{CMs}$ in all of the existing projects is low; because of the insufficient reserve to support production for a long duration, old mine layouts and presence of geological disturbances etc. The annual coal production of the whole world was $3400 \mathrm{Mt}$ in 1977 [4] and this reached $7861 \mathrm{Mt}$ by 2017 [5] with the introduction of advanced new-age technologies. 


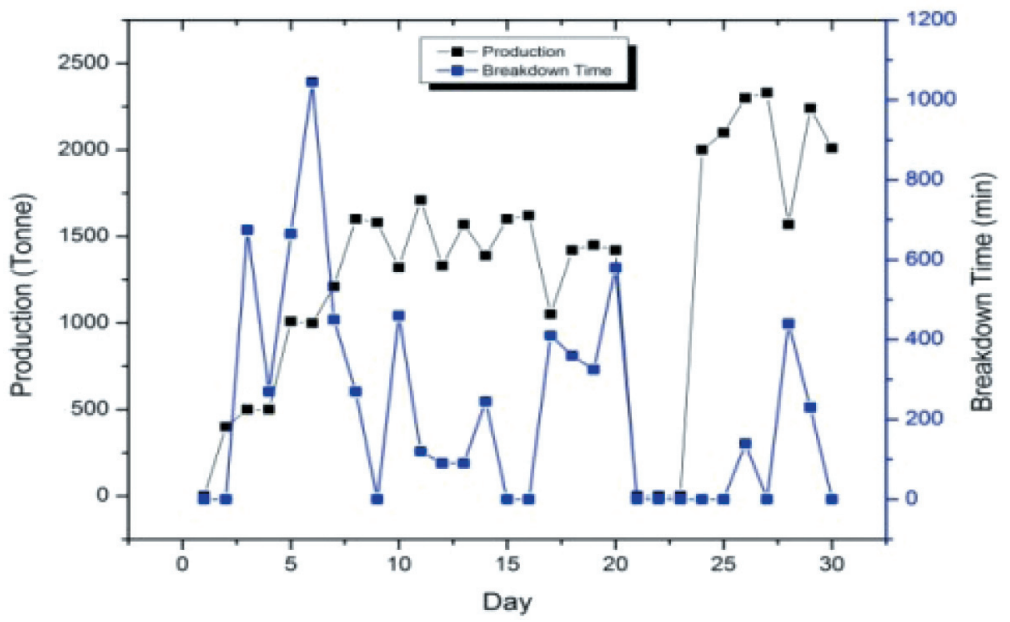

Fig. 1. Production and Breakdown trend of CM-based underground mine for one month

This paper is concentrated on a study conducted in two mines situated in the eastern part of the country that deploy total of three CMs. The first mine (Mine-A) deploys two CMs (one for development and another for depillaring) and the second (Mine-B) operates with one CM for development purpose only.

\section{METHODOLOGY}

The study was conducted for about 120 shifts of working for each CM panel. The effects of the geological conditions were compared in the two mines working with three CMs in different panels. Permissible values of these variables and effects of the actual geological conditions were observed. How these variables affect the productivity and equipment efficiency were broadly explained.

The down-time and working-time data for subsystems of CM and its allied equipment was collected from the mines and the Mean Time Between Failure (MTBF), Mean Time to Repair (MTTR) and Availability of each subsystem were calculated using the raw data collected from the mines. The following formulae were used to calculate the above-mentioned parameters [6-8]:

$$
\begin{aligned}
& \text { MTBF }=\frac{\text { Total Acutual Working Time }}{\text { Total Number of Failures }} \\
& \text { MTTR }=\frac{\text { Total Time To Repair }}{\text { Total Numbers of Repairs }}
\end{aligned}
$$

$$
\text { Availability }=\frac{\text { MTBF }}{\text { MTBF }+ \text { MTTR }}
$$

The percentage of failure of each subsystem with respect to the total failure time was also evaluated.

Then, trend test and serial correlation tests were performed for each CM-based failure data prior to fitting the appropriate probability distributions; these tests verify the Identical Distribution and Independence of the data set. The classical statistical techniques are useful for the independent data set [8]. The best-fit probability distribution was then selected, and the reliabilities of the subsystems were obtained graphically. Here, different probability distributions were performed using MATLAB 2013a. The best-fit probability distribution was used to measure the reliability.

In this paper, the three least- available subsystems for each $\mathrm{CM}$ and its allied equipment were considered. The other subsystems have an overly negligible record of downtime to impact on production loss.

\section{VARIABLES AFFECTING UNDERGROUND MINE PRODUCTION}

Underground mine production depends on several mining variables that have noteworthy impact on coal production. According to the Coal Mines Regulation of 1957, some of these variables can range within a specified limit for safety and productivity purposes. A few of these factors are as follows [9]:

\subsection{Thickness of seam}

This characterizes the volume of extractable coal present in the panel (the working place for the $\mathrm{CM}$ ). 
Lower seam thickness results in a low amount of coal production from a single heading in a single pass of cutting and movement of a continuous miner. This results in considerable production loss. An extremity in higher as well as lower thicknesses of the seams does not result in a better utilization; hence, it negatively affects productivity. A seam thickness between $3.5-6.0 \mathrm{~m}$ is the optimum range to get the best performance of a CM. For thicknesses of 2.5-4.6 m, the utilization is medium and seams with thicknesses less than $2.0 \mathrm{~m}$ are not suitable to work with a CM [10].

\subsection{Pillar size}

Pillar sizes in underground coal mines vary depending mainly on the depth of cover and other geological factors. Panels with smaller pillar dimensions may cause less duration for cutting, causing the frequent movement of a continuous miner between faces. Whereas, the panels with higher pillar sizes causes considerable transportation delay. Therefore, the selection of proper pillar dimension is important from both the mine safety and production purposes. Pillar sizes ranging from 20.0 to $30.0 \mathrm{~m}$ centers are optimum for the best performance of the CM-based mine operation and pillar sizes ranging from 30.0 to $45.0 \mathrm{~m}$ allows for a moderate operational performance with CMs [10].

\subsection{Gallery width}

CMs are large machines to be fitted and operated within a maximum permissible gallery width of $4.8 \mathrm{~m}$ as per the Coal Mines Regulation. A standard CM has a $3.6 \mathrm{~m}$ cutter width, demanding a relatively larger gallery width for efficient operation. Depending on the strata condition, these machines can be safe and productive at higher gallery widths of $5 \mathrm{~m}$ to $6.6 \mathrm{~m}$. For higher gallery widths, a Continuous Miner gets more volume of coal at a single heading. In India as per the Coal Mines Regulation 1957, $4.8 \mathrm{~m}$ is the maximum permissible gallery width, though the optimum performance of a CM can be achieved at this gallery width while moderate performance is achieved up to a width of $4.0 \mathrm{~m}$; a further lowering of gallery width is not at all suitable for CM-based working.

\subsection{Gradient}

The transportation equipment speed and efficiency get drastically reduced with an increase in the gradient; this adversely affects the transport equipment cycle time and disrupts overall productivity. A gradient of not steeper than 1 in 10 is optimum for a CM-based production system [10]; a gradient of 1 in 8 results in a lesser efficiency of the transport equipment and hence reduces the overall efficiency of the CM-based production system, whereas a gradient of 1 in 5 or higher severely affects the efficiency of a CM-based system. The values of the parameters discussed above are presented in Table 1.

Table 1

Geo-mining condition of mines under study

\begin{tabular}{|c|c|c|c|c|c|}
\hline Mine & $\begin{array}{c}\text { Seams } \\
\text { working } \\
\text { with CM }\end{array}$ & $\begin{array}{c}\text { Thickness } \\
\text { of seam } \\
{[\mathbf{m}]}\end{array}$ & $\begin{array}{c}\text { Pillar } \\
\text { Size } \\
{[\mathbf{m}]}\end{array}$ & $\begin{array}{c}\text { Gallery } \\
\text { width } \\
{[\mathbf{m}]}\end{array}$ & Gradient \\
\hline Mine-A & 2 & $4.0-5.0$ & $32 \times 32$ & 6.0 & 1 in 16 \\
\hline Mine-B & 1 & 4.75 & $34 \times 34$ & 6.0 & 1 in 15 \\
\hline
\end{tabular}

\section{RESULT AND DISCUSSION}

In the corresponding study, the overall system is broadly divided into several subsystems; some of them are integral parts of the $\mathrm{CM}$ and others are important in respect to the overall performance of the CM-based system. Therefore, failure of any of these subsystems disrupts the CM-based production; namely, the subsystems are- the electrical parts of the $\mathrm{CM}$ and its allied equipment, traction of the $\mathrm{CM}$, gathering arm of the $\mathrm{CM}$, cutting drum, hydraulic systems, feeder breaker, conveyors of the CM and overall mine conveying system. The percentage of downtime caused by any of the subsystems among the overall downtime and availability of each subsystem is presented in Table 2 .

Table 2 indicates that, outbye Conveyor, CM Conveyor, Electrical systems have the lowest equipment availability for CM-1based systems. For CM-2 based systems, the conveyor, electrical systems and gathering arm have the least availability; whereas for the $\mathrm{CM}$ of Mine-B, the subsystems with least availability are - the Conveyor, Electrical and Shuttle car.

The reliability analyses of three subsystems with the least availability for each of the CMs are presented in the scope of this paper. At first, the relationship between the cumulative failure number and cumulative Time Between Failures were plotted graphically to see the trend; if the plotted graph is almost linear it signifies no trend in failure rates [8]. Then, Time Between Failures for the $\mathrm{i}^{\text {th }}$ time vs. the $(\mathrm{i}-1)^{\text {th }}$ time were 
Table 2

Percentage of total downtime and availability of all associated subsystems of CMs

\begin{tabular}{|l|c|c|c|c|c|c|}
\hline \multirow{2}{*}{$\begin{array}{c}\text { Name } \\
\text { of Subsystem }\end{array}$} & \multicolumn{2}{|c|}{ CM-1 of Mine-A } & \multicolumn{2}{c|}{ CM-2 of Mine-A } & \multicolumn{2}{c|}{ CM of Mine-B } \\
\cline { 2 - 7 } & $\begin{array}{c}\text { Percent } \\
\text { DT. }\end{array}$ & Availability & $\begin{array}{c}\text { Percent } \\
\text { DT. }\end{array}$ & Availability & $\begin{array}{c}\text { Percent } \\
\text { DT. }\end{array}$ & Availability \\
\hline Electrical & 3.69 & 98.53 & 8.34 & 95.77 & 32.18 & 93.85 \\
\hline Cutter & 0.34 & 99.87 & 1.28 & 99.35 & 0.88 & 99.83 \\
\hline Gathering & 0.96 & 99.62 & 7.55 & 96.17 & 6.04 & 98.85 \\
\hline Traction & 3.27 & 98.70 & 1.90 & 99.04 & 0.00 & 100.00 \\
\hline Hydraulic & 1.30 & 99.48 & 2.01 & 98.98 & 2.34 & 99.55 \\
\hline Chassis & 0.08 & 99.50 & 0.13 & 99.93 & 0.70 & 99.87 \\
\hline S/C & 2.16 & 99.14 & 5.19 & 97.36 & 8.79 & 98.32 \\
\hline Maint. & 4.09 & 99.30 & 13.09 & 93.36 & 3.34 & 99.36 \\
\hline Conveyor & 76.57 & 69.56 & 55.02 & 72.96 & 41.50 & 92.07 \\
\hline F/B & 0.93 & 99.63 & 0.18 & 99.91 & 1.41 & 99.73 \\
\hline CM Con. & 6.62 & 97.37 & 5.32 & 97.30 & 2.81 & 99.46 \\
\hline
\end{tabular}

Legend: Percent DT. = Percentage Downtime among Overall Downtime; S/C = Shuttle Car; F/B = Feeder Breaker; Maint. = Extended Maintenance Time; CM Con. = CM Conveyor

scatter plotted to verify any correlation between them; if there is no specific trend in the scatter plot, this signifies that the data is free from any correlation [8].

\subsection{Statistical significance and mathematical relationship}

Subsequently, the proper probability distributions were fitted to the data to determine the reliability of the subsystems. In the reliability analysis of the repairable systems, three types of probability distributions are generally used: Weibull Distribution, Lognormal Distribution and Exponential Distribution. The goodness of fit was measured by the Chi-Square test. The failure data related to an individual subsystem was fitted to the appropriate distributions and the reliability was obtained and presented here graphically.

Figure 2 represents the results of the trend and serial correlation tests of CM- 1 in Mine-A. The trend test is the line plot between the cumulative failure number and cumulative Time Between Failures [8]. The serial correlation test is a scatter plot between the $i^{\text {th }}$ Time Between Failure and $(\mathrm{i}-1)^{\text {th }}$ Time Between Failure [6, 8].

The trend test plot shows a linear trend; hence there is no trend present in the failure data. The serial correlation test shows no specific trend through the scattered data plot; hence, no correlation is present.
This signifies the absence of any trend and serial correlation in the failure data of CM-1 in Mine-A. Similar tests were also performed on the other two CM-based failure data and shows similar results as the CM-1.

After this, the data sets were analyzed using compatible probability distributions for their reliability analysis.
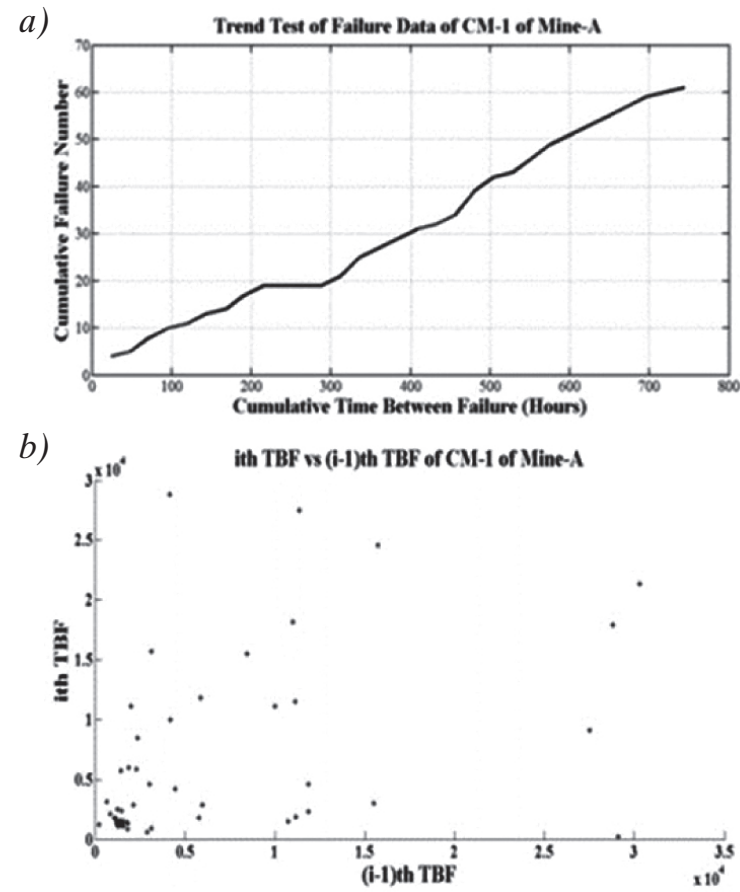

Fig. 2. Trend Test (a) and Serial Correlation Test Plots (b) of $C M-1$ in Mine- $A$ 
Figure 3 depicts the reliability of the electrical systems associated with the three CMs and their allied equipment; as the electrical system was found to be

a)

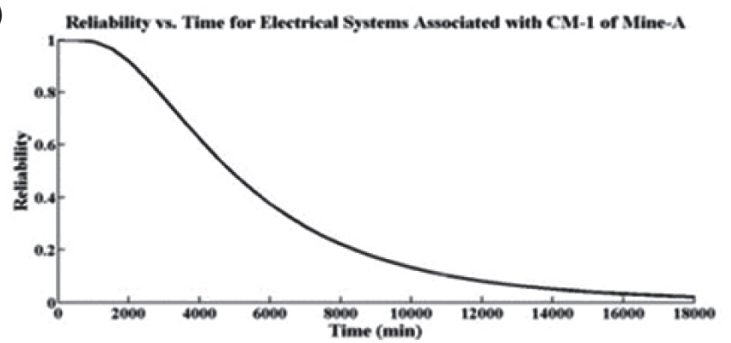

b)

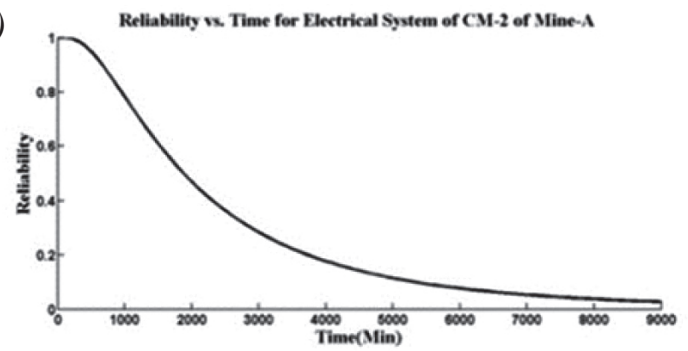

c)

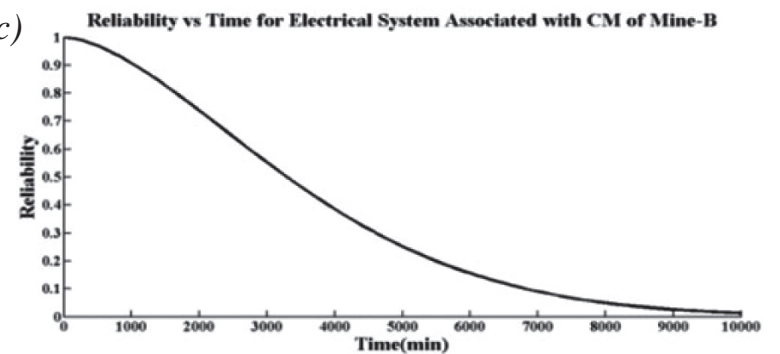

Fig. 3. Reliability of Electrical Systems Associated with $C M-1$ (a), CM-2 of Mine- $A$ (b), and CM of Mine-B (c) common among the three subsystems with a lower availability for all three CMs. A similar study was also conducted for the other two lower availability systems of each CM. Initially, the reliability of each subsystem was $100 \%$, with an increase in operating time reliability generally decreases. From the analysis, CM-1 based system of Mine-A shows the lowest reliability of the mine conveyors; reaching $50 \%$ reliability in just 1500-1600 minutes of operation, and its electrical and $\mathrm{CM}$ conveyor reaching $50 \%$ reliability after 4500-4600 and 7200-7300 minutes of operation. A similar low reliability trend was also observed for the conveyor associated with the CM-2 based production system of Mine-A, whereas, the electrical system of CM-2 and its allied equipment reaches $50 \%$ reliability after 2000-2200 minutes of operation and the gathering arm of CM-2 depicts $50 \%$ reliability after $7500-7700$ minutes of operation. The conveyor in Mine-B described a better reliability trend, reaching $50 \%$ reliability after 3500-3800 minutes of operation, whereas the electrical system takes 3300-3500 minutes to reach 50\% reliability and the reliability of the shuttle car reaches to $50 \%$ after $6000-6500$ minutes of operation.

A statistical analysis of the CM-2 of Mine-A and $\mathrm{CM}$ of Mine-B are presented in Table 3. Where, the hydraulic systems and conveyors of the two CMs depicted significant variation for their corresponding working conditions.

Table 3

Significance test of TBF data of CM-2 of Mine-A and CM of Mine-B

\begin{tabular}{|c|c|c|c|c|c|}
\hline Name of Subsystem & CM / Mine & Mean & Min & Max & Pearson's t-Test \\
\hline \multirow{2}{*}{ Electrical } & CM-2 Mine-A & 2520.3 & 385.0 & 8585.0 & \multirow{2}{*}{ NS } \\
\hline & CM Mine-B & 3682.5 & 580.0 & 7200.0 & \\
\hline \multirow{2}{*}{ Cutter } & CM-2 Mine-A & 27217.5 & 25995.0 & 28440.0 & \multirow{2}{*}{ NS } \\
\hline & CM Mine-B & 30240.0 & 30240.0 & 30240.0 & \\
\hline \multirow{2}{*}{ Gathering } & CM-2 Mine-A & 6255.0 & 1285.0 & 19455.0 & \multirow{2}{*}{ NS } \\
\hline & CM Mine-B & 21840.0 & 480.0 & 43200.0 & \\
\hline \multirow{2}{*}{ Hydraulic } & CM-2 Mine-A & 5917.6 & 545.0 & 23645.0 & \multirow{2}{*}{$\mathrm{S}$} \\
\hline & CM Mine-B & 18267.5 & 13495.0 & 23040.0 & \\
\hline \multirow{2}{*}{ Chassis } & CM-2 of Mine-A & 18820.0 & 18820.0 & 18820.0 & \multirow{2}{*}{ NS } \\
\hline & CM of Mine-B & 21600.0 & 21600.0 & 21600.0 & \\
\hline \multirow{2}{*}{ Shuttle car } & CM-2 of Mine-A & 3407.69 & 510.0 .0 & 11735.0 & \multirow{2}{*}{ NS } \\
\hline & CM of Mine-B & 7554.0 & 1880.0 & 20550.0 & \\
\hline \multirow{2}{*}{ Feeder breaker } & CM-2 of Mine-A & 7150.0 & 4940.0 & 9360.0 & \multirow{2}{*}{ NS } \\
\hline & CM of Mine-B & 8640.0 & 8640.0 & 8640.0 & \\
\hline \multirow{2}{*}{ Conveyor } & CM-2 of Mine-A & 1937.7 & 525.0 & 5400.0 & \multirow{2}{*}{$\mathrm{S}$} \\
\hline & $\mathrm{CM}$ of Mine-B & 3648.5 & 765.0 & 9265.0 & \\
\hline
\end{tabular}

Legends: NS $=$ Non-Significant $(>0.05) ; \mathrm{S}=$ Significant $(<0.05) ; \mathrm{TBF}=$ Time Between Failure 


\section{MAINTENANCE OF CM AND ALLIED SUBSYSTEMS}

The current study shows a considerable production and resource loss due to equipment downtimes, imposing the requirement of a proper preventive maintenance schedule of the low-reliability subsystems of the CM-based mining operation. Preventive maintenance is carried out before the next forecasted failure occurs.

\subsection{Conveyor}

Conveyors are required to be inspected at least once daily by walking through the sides and looking for any abnormalities. The preventive maintenance includes inspection of the rollers, pulleys and wheels for their alignment, motor noise check and lubrication, sprocket alignment, lubrication of all moving parts and bearings as per manufacturer guidelines [11]. A proper strategic maintenance program should be designed for the overall equipment fleets.

\section{2. $\mathrm{CM}$}

The operators should be assigned to inspect the machine condition before and after machine operation. A general inspection includes hydraulic-systems check, such as checking the cylinders for any leakages, checking of the cutter for any abnormality, gathering head assembly, gathering head motor, and control systems checks $[12,13]$.

\subsection{Electrical Systems}

The electrical failure was also significant in this study, causing power interruption for the working of vital machines. The regular inspection of the power transformer, gate end box, and supply cables are important. The handling of the power transmission cable during operation of the CM and shuttle car should be done with proper care.

\section{CONCLUSION}

The reliability and availability of equipment designates the dependability and sturdiness of production equipment. A reliability analysis of the CM-based underground mining operation describes that, the CM-based system in India has a considerable scope of improvement in the near future, along with the introduction of new CM-based projects in the country. In this paper, the reliability and availability analysis of three CMs working in two mines are studied; it shows that the maintenance program for the CM and its allied equipment has to be designed in a strategic way to improve the return on investment ratio. All of the subsystems of the overall CM-based system require attention for the proper maintenance. However, the reliability of the conveyor systems of all of the mine panels and electrical systems were found to be critical from a reliability point of view and needs more attention in regards to their maintenance aspect. The reliability criteria can be used to design a strategic maintenance schedule to prevent failures and improve utilization and productivity.

\section{SUMMARY}

This paper focuses on the effects of different geomining factors and downtime of a Continuous Miner (CM) and its allied equipment on underground coal mine production. The availability of the different subsystems of the CM and its associated equipment was determined. Subsequently, best-fit probability distributions were used to determine the reliability of the three least-available subsystems for each CM. Finally, a maintenance plan is prescribed to augment CM-based production.

\section{Acknowledgement}

The author would like to thank the officials of Eastern Coalfields Limited for giving their approval of the study and for their constant support. The author would also like to thank Prof. N.C. Dey, Professor of Mining Engineering in IIEST, Shibpur, India for his valuable insights, suggestions and support.

\section{References}

[1] Annual Coal Report 2016-17, Chapter - 6, Ministry of Coal Government of India, http://coal.nic.in/sites/upload_files/ coal/files/coalupload/chap6AnnualReport1617en.pdf [14.07.2017].

[2] The Indian coal sector: Challenges and future outlook, Indian Chamber of Commerce, https:/www.pwc.in/assets/pdfs/ industries/power-mining/icc-coal-report.pdf [14.07.2017]. 
[3] Bridging the gap Increasing coal production and sector augmentation, Indian Chamber of Commerce, https://www.pwc.in/ assets/pdfs/publications/2016/icc-pwc-coal-report-june.pdf [14.07.2017]

[4] Griffith E.D., Clarke A.W.: World coal production, "Scientific American" 1979, 240, 1: 38-47.

[5] World energy resources Coal 2016, World Energy Council, https://www.worldenergy.org/wpcontent/uploads/2017/03/ WEResources_Coal_2016.pdf [13.12.2017].

[6] Rahimdel M.J., Hosienie S.H., Ataei M., Khalokakaei R. The reliability and maintainability analysis of pneumatic system of rotary drilling machines, "Journal of The Institution of Engineers (India): Series D” 2013, 94, 2: 105-111.

[7] Rohani H., Roosta A.K.: Calculating Total System Availability, Information Services Organization KLM-Air France, Amsterdam 2014.

[8] Vagenas N., Runciman N., Clément S.R.: A methodology for maintenance analysis of mining equipment, "International Journal of Surface Mining. Reclamation and Environment" 1997, 11: 33-40.

[9] Raghavan V., Ariff S., Kumar P.P.: Optimum Utilisation of Continuous Miner for Improving Production in Underground Coal Mines, "International Journal of Scientific and Research Publications" 2014, 4,10: 374.
[10] Modi J., Bharti S., Kant R.: Applicability of Continuous Miner in Room and Pillar Mining System: Higher Production and Productivity with Safety, International Conference on Deep Excavation, Energy Resource and Production, Kharagpur 2017.

[11] Lubrication and maintenance check list, Automated Conveyor, INC, http://www.automatedconveyors.com/acrobat/maintenance_schedule.pdf [18.07.2017].

[12] De Clercq F.J.: Maintenance planning and optimal replacement of sub-assemblies for Continuous Miners, Published as a domain property of University of Pretoria, Pretoria 2009.

[13] Safety and Maintenance Checklist, Caterpilar, http://s7d2. scene7.com/is/content/Caterpillar/C10868548 [18.07.2017].

BANERJEE SUMIT

Department of Mining Engineering Indian Institute of Engineering Science and Technology, Shibpur Howrah - 711103, West Bengal, India sumit.banerjee92@yahoo.com 


\title{
Zwiększenie wydajności kombajnów chodnikowych urabiających liniowo stosowanych w podstawowym systemie eksploatacyjnym w Indiach - podejście oparte na niezawodności
}

\begin{abstract}
Kombajny chodnikowe urabiające liniowo (CM) to stosowane na calym świecie maszyny, zdolne do wydatnego zwiększenia produkcji $w$ kopalniach podziemnych $w$ systemach filarowo-komorowych; w przyszłości będa one niezbędne do wzrostu produkcji. Jednak czynniki geologiczne i inne parametry górnicze w wielu kopalniach podziemnych nie zawsze pozwalają na osiagnięcie największej produktywności tych maszyn. W artykule przeprowadzono analize wptywu wybranych parametrów górniczych, takich jak wymiary filara, nachylenie złoża, liczba pasów i zastosowany sprzęt na wydajność $w$ systemie produkcji opartym na kombajnie typu CM, i opracowano prognoze trendów. Wyniki przeprowadzonych badań umożliwiają określenie skutków awarii kombajnu typu CM $i$ wspótpracujacych z nim urządzeń i maszyn; czasy awarii kombajnu typu CM $i$ zwiazanych $z$ nim urzadzeń zostały oszacowane tącznie. W pracy uwzględniono wystapienie prawdopodobieństwa tego typu awarii oraz ich wiarygodność.

Przeprowadzone badania wskazuja, że awarie przenośnika odstawczego najbardziej wplywaja na wydajność kompleksu CM, a inne awarie wptywajace w znacznym stopniu na produktywność to awarie elektryczne $i$ hydrauliczne, awarie wozów odstawczych, problem $z$ gromadzeniem urobku, problemy $w$ procesie urabiania oraz przemieszczania maszyny. Analiza niezawodnościowa każdej grupy komponentów kompleksu CM umożliwi opracowanie harmonogramu konserwacji i prognozowanie częstotliwości inspekcji tych komponentów w celu zmniejszenia liczby awarii i zwiększenia ich dyspozycyjności.
\end{abstract}

Słowa kluczowe: kombajn chodnikowy urabiajacy liniowo, wymiar filaru, liczba pasów, niezawodność, procent awarii

\section{WSTĘP}

Zasoby węgla znajdujące się w pobliżu powierzchni są coraz bardziej wyczerpane, co w najbliższej przyszłości doprowadzi do konieczności wydobycia węgla z głębszych pokładów. Podziemne wydobycie do tej pory jest jedyną ekonomiczną techniką eksploatacji węgla z pokładów zalegających na większej głębokości. Indie są jednym z pięciu największych producentów węgla na świecie z produkcją 639,23 mln MG tego surowca w latach 2015-2016 [1], jednak taka wielkość wydobycia nie pozwala na eksport, a nawet na zaspokojenie rodzimego popytu. Oczekuje się, że zapotrzebowanie w Indiach na węgiel wzrośnie do 1373 mln MG w latach 2021-2022 [2]. W związku z tym Indie zaplanowały zwiększyć całkowitą produkcję węgla do co najmniej 1 mld MG do 2020 r. [3]. Plan ten wymaga zastosowania eksploatacji podziemnej w celu wydobycia węgla $\mathrm{z}$ głębszych pokładów. 


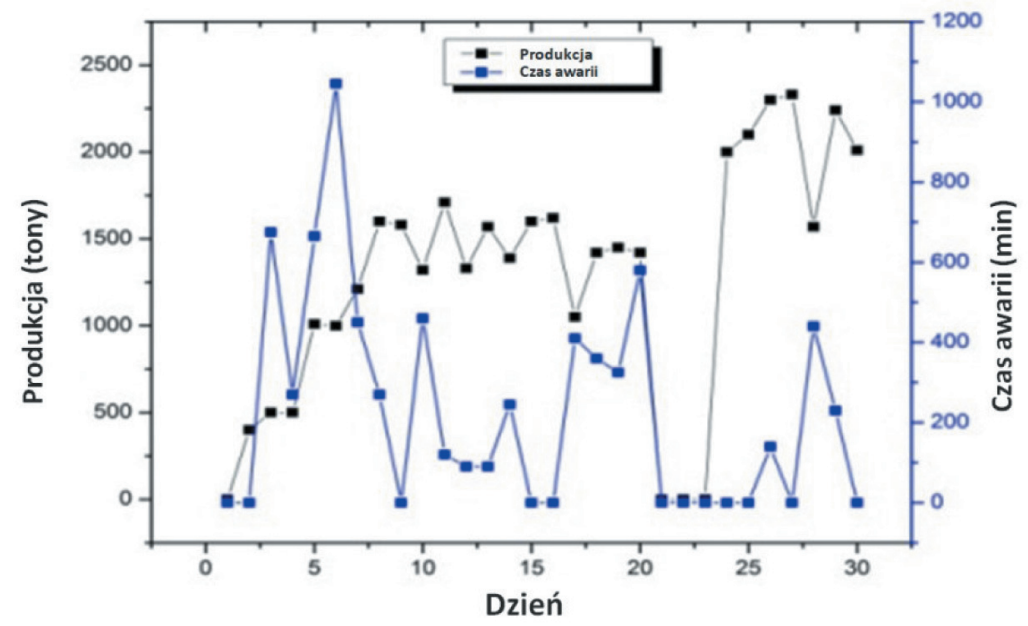

Rys. 1. Wielkość wydobycia i czas występujących awarii w kopalni wykorzystuącej kombajn typu CM $w$ ciagu miesiaca

W większości indyjskich podziemnych kopalni węgla kamiennego eksploatacja odbywa się na podstawie metody Borda i Pillara (odmiana metody filarowo-komorowej) z wykorzystaniem wiercenia, ładowania i strzelania do produkcji węgla oraz ładowarek i wozów odstawczych do jego ładowania i odstawy. Kilka instalacji największej spółki sektora publicznego produkującej węgiel w Indiach wykorzystuje do eksploatacji węgla chodnikowe kombajny urabiające liniowo - Continuous Miner (CM) i planuje nowe inwestycje oparte na tego typu maszynach; chodnikowe kombajny urabiające liniowo są znane z wysokiej wydajności w górnictwie podziemnym (rys. 1).

Produktywność kombajnów typu CM we wszystkich eksploatowanych instalacjach jest niska ze względu na niewystarczające wsparcie tych kombajnów przez urządzenia pomocnicze w dłuższym przedziale czasowym, stary układ wyrobisk w kopalniach, w wielu przypadkach niekorzystne warunki górniczo-geologiczne itp. Roczna produkcja węgla na całym świecie wyniosła 3400 mln MG w 1977 r. [4] i osiągnęła 7861 mln MG w 2017 r. [5] wraz z wprowadzeniem zaawansowanych technologii i nowoczesnych rozwiązań maszyn.

Niniejszy artykuł przedstawia wyniki badań przeprowadzonych w dwóch kopalniach położonych we wschodniej części Indii, w których eksploatowano łącznie trzy kombajny typu CM. Pierwsza kopalnia (Mine-A) wykorzystywała dwa kombajny CM: jeden do prac przygotowawczych oznaczony CM-1, drugi do rozcinki złoża oznaczony CM-2. Druga kopalnia (Mine-B) eksploatowała jeden kombajn typu CM do prac przygotowawczych.

\section{METODOLODIA BADAWCZA}

Badanie przeprowadzono na około 120 zmianach roboczych dla każdego systemu wykorzystującego kombajn typu CM. Porównano w obu kopalniach wpływ faktycznych warunków geologicznych na ich pracę, jak również określono dopuszczalne wartości tych warunków. To, w jaki sposób zmienne warunki geologiczne wpływają na produktywność i wydajność zastosowanych maszyn i urządzeń, zostało szeroko wyjaśnione. Zostały zebrane dane dotyczące przestojów i czasu pracy systemów wykorzystujących kombajn CM oraz urządzenia pomocnicze, a średni czas między awariami (MTBF), średni czas naprawy (MTTR) i dostępność każdego systemu zostały obliczone na podstawie wiarygodnych danych uzyskanych z kopalni. Następujące wzory zostały użyte do obliczenia wyżej wymienionych czasów MTBF, MTTR oraz dostępności [6-8]:

$$
\begin{aligned}
\mathrm{MTBF} & =\frac{\text { Całkowity rzeczywisty czas pracy }}{\text { Łączna liczba awarii }} \\
\mathrm{MTTR} & =\frac{\text { Całkowity czas napraw }}{\text { Łączna liczba awarii }}
\end{aligned}
$$

$$
\text { Dostępność }=\frac{\text { MTBF }}{\mathrm{MTBF}+\mathrm{MTTR}}
$$

Oceniono również odsetek awarii każdego z komponentów eksploatowanego systemu (podsystemu) w odniesieniu do całkowitego czasu awarii. 
Następnie przeprowadzono test trendu i testy korelacji szeregowej dla każdego z systemów wykorzystujących kombajn typu CM oparte na analizie błędów przed dopasowaniem odpowiednich rozkładów prawdopodobieństwa; testy te weryfikują identyczną dystrybucję i niezależność zestawu danych. Klasyczne techniki statystyczne są przydatne dla niezależnego zbioru danych [8]. Następnie wybrano najlepszy rozkład prawdopodobieństwa, a przebieg wyników odnośnie do poszczególnych podsystemów przedstawiono graficznie. Analizę rozkładów prawdopodobieństwa przeprowadzono przy użyciu programu MATLAB 2013a. Jako najlepsze kryterium niezawodności użyto najlepszego dopasowania prawdopodobieństwa.

W niniejszym artykule rozważono trzy najmniej dyspozycyjne podsystemy każdego z systemów wykorzystujących kombajn typu CM i urządzenia pomocnicze. Pozostałe podsystemy mają pomijalny czas przestojów, aby mogły one wpłynąć na zmniejszenie produktywności systemu.

\section{ZMIENNE WPŁYWAJACCE NA WYDOBYCIE W KOPALNIACH PODZIEMNYCH}

Wielkość wydobycia w kopalniach podziemnych zależy od kilku zmiennych - parametrów górniczo-geologicznych, które mogą mieć znaczący wpływ na wydobycie węgla. Zgodnie z Indyjskim Rozporządzeniem w sprawie Górniczych Kopalń Węgla (Coal Mines Regulation) z 1957 r. niektóre z tych parametrów mogą zawierać się w określonym zakresie ze względów bezpieczeństwa i wydajności. Poniżej opisano wybrane parametry [9].

\subsection{Miąższość pokładu}

Miąższość pokładu decyduje o ilości węgla w miejscu pracy systemu z kombajnem typu CM. Mniejsza wartość ma wpływ na niską produkcję węgla w przod$\mathrm{ku}$, przy ustalonej pozycji i pojedynczym przejściu organu urabiającego kombajnu typu CM. Powoduje to znaczne zmniejszenie produktywności kombajnu. Jednak zarówno mała, jak i bardzo duża miąższość pokładu nie sprzyja dobremu wykorzystaniu kombajnu, a zatem negatywnie wpływa na jego wydajność. Miąższość pokładu od 3,5 do 6,0 m jest optymalnym zakresem, aby uzyskać najlepszą wydajność kombaj- nu typu CM, przy miąższości pokładu 2,5-4,6 m wydajność osiąga średnie rezultaty, a pokłady o miąższości mniejszej niż 2,0 $\mathrm{m}$ nie pozwalają na uzyskanie zadowalających wydajności [10].

\subsection{Rozmiar filaru}

Rozmiary filaru (jego szerokość i długość) w podziemnych kopalniach węgla zależą głównie od głębokości zalegania pokładu i innych czynników geologicznych. W systemach filarowo-komorowych o mniejszym wymiarze filara czas urabiania przodka może być krótszy, powodując częste przemieszczanie się kombajnu typu CM między przodkami. Natomiast w przypadku większych wymiarów filarów może to powodować znaczne opóźnienie w odstawie urobku. Dlatego dobór odpowiednich wymiarów filaru jest istotny zarówno z punktu widzenia bezpieczeństwa kopalni, jak i wymaganej wydajności. Wielkość filaru w zakresie od 20,0 m do 30,0 m jest optymalna do uzyskania najlepszych wyników wydobycia w kopalni w systemie filarowo-komorowym przy wykorzystaniu kombajnu typu CM, a wymiary filaru w zakresie od $30,0 \mathrm{~m}$ do $45,0 \mathrm{~m}$ pozwalają uzyskać umiarkowaną wydajność tego kombajnu [10].

\subsection{Szerokość chodnika}

Kombajny chodnikowe typu CM to duże maszyny, które można zabudować i eksploatować w ramach maksymalnej dopuszczalnej szerokości chodnika wynoszącej 4,8 m zgodnie $\mathrm{z}$ indyjskim rozporządzeniem w sprawie kopalń (Coal Mines Regulation). Typowy kombajn CM stosowany w badanych kopalniach ma organ urabiający o szerokości 3,6 m i wymaga większej szerokości chodnika w celu uzyskania wysokiej produktywności. W zależności od warunków górotworu maszyny te mogą pracować bezpiecznie i wydajnie przy większych szerokościach chodnika od $5 \mathrm{~m}$ do $6,6 \mathrm{~m}$. W przypadku większych szerokości chodnika kombajn typu CM umożliwia uzyskanie większego wolumenu urobku w jednym przejściu głowicy urabiającej. W Indiach, zgodnie $\mathrm{z}$ rozporządzeniem $\mathrm{w}$ sprawie kopalń węgla z 1957 r., 4,8 m to maksymalna dopuszczalna szerokość chodnika, która pozwala na uzyskanie wysokich wydajności urabiania, przy szerokości chodnika 4,0 m wydajności te osiągają wartości umiarkowane, natomiast mniejsza szerokość chodnika nie jest w ogóle odpowiednia do pracy $\mathrm{z}$ wykorzystaniem kombajnów typu CM. 


\subsection{Nachylenie wyrobiska}

Szybkość przemieszczania i wydajność maszyn do odstawy urobku zostaje drastycznie zmniejszona wraz ze wzrostem nachylenia wyrobiska; wpływa to niekorzystnie na czas cyklu maszyn odstawczych i zakłóca ich sumaryczną produktywność. Nachylenie wyrobiska nie większe niż $1-10^{\circ}$ jest optymalne dla systemu produkcji opartego na kombajnach typu CM [10], nachylenie $1-8^{\circ}$ wpływa na mniejszą wydajność maszyn odstawczych, a tym samym zmniejsza ogólną wydajność systemu produkcyjnego opartego na kombajnach typu $\mathrm{CM}$, podczas gdy nachylenie $1-5^{\circ}$ lub wyższe poważnie wpływa na obniżenie wydajności systemu. Wartości omawianych powyżej parametrów w badanych kopalniach przedstawiono w tabeli 1 .

Tabela 1

Warunki górniczo-geologiczne w kopalniach w czasie badań

\begin{tabular}{|c|c|c|c|c|c|}
\hline $\begin{array}{c}\text { Kopal- } \\
\text { nia }\end{array}$ & $\begin{array}{c}\text { Liczba } \\
\text { pokładów } \\
\text { eksploato- } \\
\text { wanych CM }\end{array}$ & $\begin{array}{c}\text { Miąź- } \\
\text { szość } \\
\text { pokładu } \\
{[\mathbf{m}]}\end{array}$ & $\begin{array}{c}\text { Wymia- } \\
\text { ry } \\
\text { filara } \\
{[\mathbf{m}]}\end{array}$ & $\begin{array}{c}\text { Szero- } \\
\text { kość } \\
\text { chod- } \\
\text { nika } \\
{[\mathbf{m}]}\end{array}$ & $\begin{array}{c}\text { Nachy- } \\
\text { lenie }\end{array}$ \\
\hline Mine-A & 2 & $4,05,0$ & $32 \times 32$ & 6,0 & $1-16$ \\
\hline Mine-B & 1 & 4,75 & $34 \times 34$ & 6,0 & $1-15$ \\
\hline
\end{tabular}

\section{WYNIK BADAŃ I DYSKUSJA}

W przeprowadzonych badaniach system eksploatacyjny wykorzystujący kombajn typu CM został zasadniczo podzielony na kilka podsystemów; niektóre z nich stanowia integralną część kombajnu, a inne są ważne z uwagi na ogólną wydajność badanego systemu. Dlatego awaria lub przestój któregokolwiek z tych podsystemów zakłóca produktywność całego systemu opartego na kombajnie typu CM. Są to następujące podsystemy: układ zasilania elektrycznego kombajnu CM i urządzeń pomocniczych, układ napędowy kombajnu CM, układ ładowania urobku, głowica urabiająca, systemy hydrauliczne, podawarka, przenośnik kombajnu CM i system odstawy urobku z przodka. Procent przestojów spowodowanych przez dowolny z podsystemów w porównaniu z całkowitym czasem przestoju i dostępnością każdego podsystemu przedstawiono w tabeli 2 .

Zgodnie z zamieszczonymi wynikami można stwierdzić, że przenośnik odstawy kopalnianej głównej, przenośnik kombajnu CM oraz podsystemy elektryczne mają najniższą dostępność sprzętu w przypadku instalacji wykorzystującej kombajn oznaczony CM-1, instalacji wykorzystującej kombajn oznaczony jako CM-2. Podobnie najmniejszą dostępność mają przenośniki odstawy głównej, układ instalacji elektrycznej

Tabela2

Procent całkowitego czasu przestoju i dostępności wszystkich powiązanych podsystemów CM

\begin{tabular}{|l|c|c|c|c|c|c|}
\hline \multirow{2}{*}{ Nazwa podsystemu } & \multicolumn{2}{|c|}{ CM-1 Mine-A } & \multicolumn{2}{c|}{ CM-2 Mine-A } & \multicolumn{2}{c|}{ CM Mine-B } \\
\cline { 2 - 7 } & $\begin{array}{c}\text { Czas } \\
\text { przestoju / } \\
\text { ogółem [\%] }\end{array}$ & $\begin{array}{c}\text { Dostępność } \\
{[\%]}\end{array}$ & $\begin{array}{c}\text { Czas } \\
\text { przestoju / } \\
\text { ogółem [\%] }\end{array}$ & $\begin{array}{c}\text { Dostępność } \\
{[\%]}\end{array}$ & $\begin{array}{c}\text { Czas } \\
\text { przestoju/ } \\
\text { ogółem } \\
{[\%]}\end{array}$ & $\begin{array}{c}\text { Dostępność } \\
{[\%]}\end{array}$ \\
\hline Zasilanie elektryczne & 3,69 & 98,53 & 8,34 & 95,77 & 32,18 & 93,85 \\
\hline Głowica urabiająca & 0,34 & 99,87 & 1,280 & 99,35 & 0,88 & 99,83 \\
\hline Eadowanie urobku & 0,96 & 99,62 & 7,55 & 96,17 & 6,04 & 98,85 \\
\hline Układ napędowy & 3,27 & 98,70 & 1,90 & 99,04 & 0 & 100 \\
\hline Hydraulika & 1,30 & 99,48 & 2,01 & 98,98 & 2,34 & 99,55 \\
\hline Podwozie & 0,08 & 99,50 & 0,13 & 99,93 & 0,7 & 99,87 \\
\hline Wóz odstawczy & 2,16 & 99,14 & 5,19 & 97,36 & 8,79 & 98,32 \\
\hline Konserwacja & 4,09 & 99,30 & 13,09 & 93,36 & 3,34 & 99,36 \\
\hline Przenośnik & 76,57 & 69,56 & 55,02 & 72,96 & 41,50 & 92,07 \\
\hline Podajnik & 0,93 & 99,63 & 0,18 & 99,91 & 1,41 & 99,73 \\
\hline $\begin{array}{l}\text { Przenośnik kombajnu } \\
\text { CM }\end{array}$ & 6,62 & 97,37 & 5,32 & 97,30 & 2,81 & 99,46 \\
\hline
\end{tabular}


oraz układ ładowania urobku. W przypadku kombajnu z kopalni Mine-B podsystemy o najmniejszej dostępności to: przenośniki odstawy głównej, układ instalacji elektrycznej i wozy odstawcze.

Analizy niezawodności trzech podsystemów o najmniejszej dostępności dla każdego z badanych kombajnów typu $\mathrm{CM}$ przedstawiono w treści niniejszego artykułu. W pierwszej kolejności przedstawiono graficznie zależność pomiędzy łączną liczbą awarii i skumulowanym czasem między awariami, aby zaobserwować trend. Jeżeli uzyskana zależność jest prawie liniowa, oznacza to brak tendencji w zakresie awaryjności [8]. Następnie został naniesiony na wykres czas między awariami dla $i$-tej oraz $i$ - 1 awarii w celu sprawdzenia jakiejkolwiek korelacji między nimi. Jeśli nie zaobserwowano określonego trendu na wykresie, a dane są rozproszone, oznacza to, że są one wolne od jakiejkolwiek korelacji [8].

\subsection{Istotność statystyczna i relacja matematyczna}

Zgodnie z powyższym do otrzymanych danych dopasowano odpowiednie rozkłady prawdopodobieństwa w celu określenia niezawodności poszczególnych podsystemów. $\mathrm{W}$ analizie niezawodności systemów naprawialnych stosuje się ogólnie trzy typy rozkładów prawdopodobieństwa: dystrybucję Weibulla, dystrybucję lognormalną i dystrybucję wykładniczą. Dokładność dopasowania mierzono testem chi-Square. Dane dotyczące awarii odnoszące się do poszczególnych podsystemów zostały dopasowane do odpowiednich rozkładów, a otrzymana niezawodność została przedstawiona graficznie na rysunku 2.

Rysunek 2a przedstawia wyniki testu trendu (LHS) i seryjnego testu korelacji dla kombajnu oznaczonego CM-1 z kopalni Mine-A. Test trendu to wykres liniowy pomiędzy łączną liczbą awarii i skumulowanym czasem między nimi [8]. Test korelacji szeregowej (RHS) przedstawiający zależności czasowe między awariami dla $i$-tej oraz $i$-1 awarii (rys. 2b) jest wykresem rozproszonym $[6,8]$.

Wykres testu trendu (LHS) pokazuje trend liniowy, dlatego nie można określić trendu dla otrzymanych wyników dotyczących awarii. Test korelacji szeregowej (RHS) również nie wykazuje określonego trendu na wykresie rozproszonym; nie ma żadnej korelacji. Oznacza to brak jakiegokolwiek trendu i korelacji sze- regowej w przypadku danych o awariach systemu z kombajnem oznaczonym jako CM-1 z kopalni Mine-A.
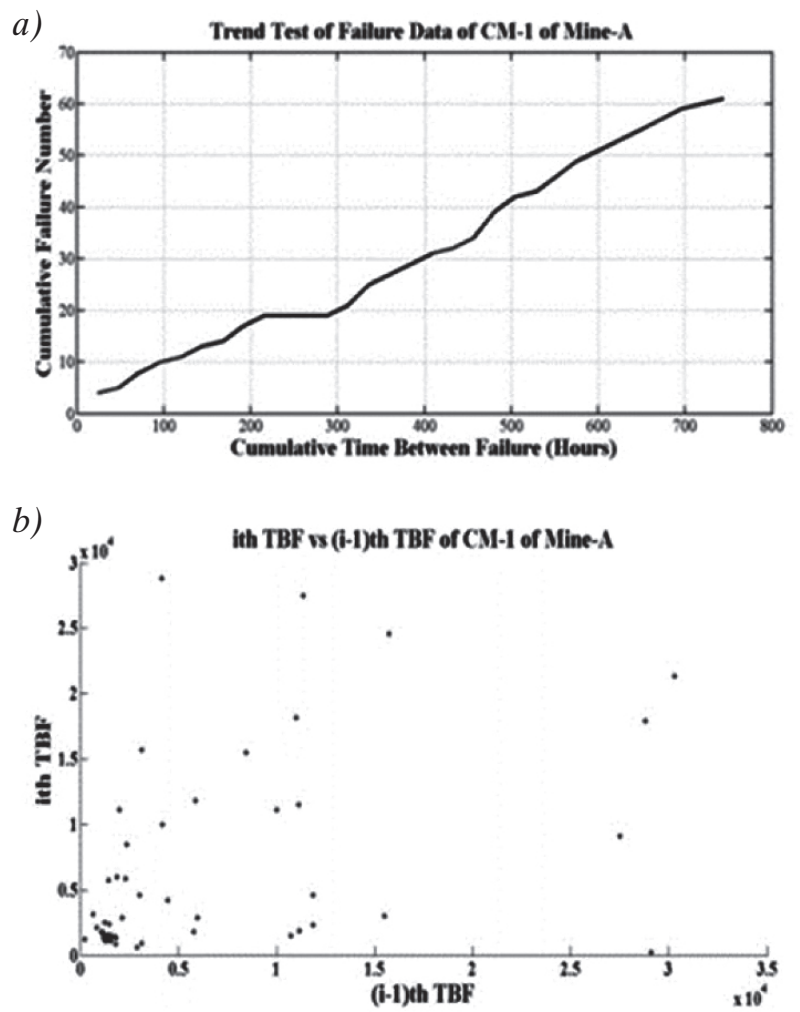

Rys. 2. Wykres testu trendu (LHS) (a) i testu korelacji szeregowej (RHS) (b) dla kombajnu oznaczonego CM-1 z kopalni Mine-A

Podobne testy przeprowadzono również $\mathrm{z}$ wykorzystaniem innych danych dotyczących awarii dwóch pozostałych systemów z kombajnem oznaczonym jako CM-2 z kopalni Mine-A i kombajnem z kopalni Mine-B. Uzyskano podobne wyniki. Następnie zestawy danych przeanalizowano przy użyciu zgodnych rozkładów prawdopodobieństwa w celu określenia ich niezawodności.

Na rysunku 3 przedstawiono wykresy niezawodności podsystemów elektrycznych zasilających kombajny oraz urządzenia pomocnicze, ponieważ stwierdzono, że podsystem elektryczny wszystkich trzech badanych kombajnów typu CM charakteryzuje się niską dostępnością.

Podobne badanie przeprowadzono również w przypadku dwóch pozostałych podsystemów o niskiej dostępności dla każdego z badanych kombajnów typu CM. Początkowo niezawodność każdego podsystemu wynosiła $100 \%$, a z czasem pracy zaczęła spadać. $\mathrm{Z}$ analizy wynika, że system w kopalni Mine-A z kombajnem oznaczonym CM-1 wykazuje najniższą 


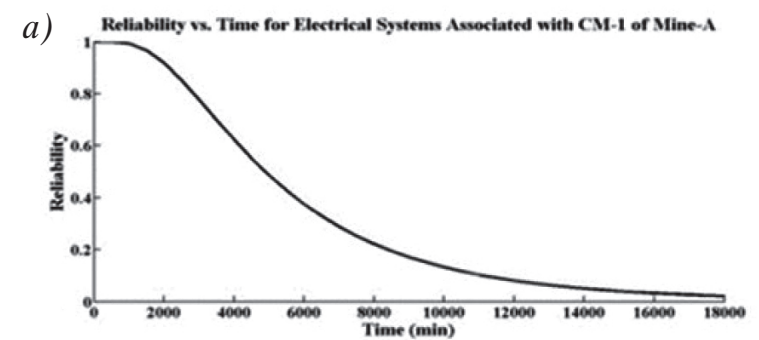

b)

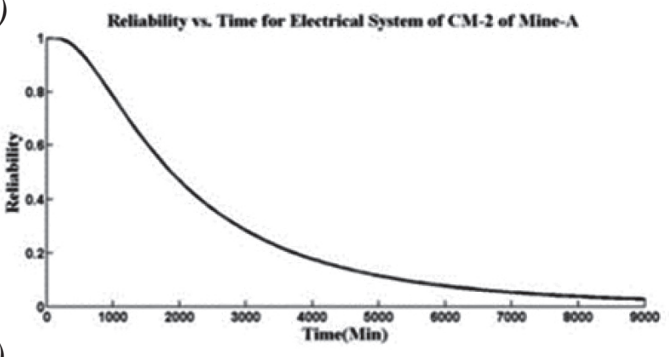

c)

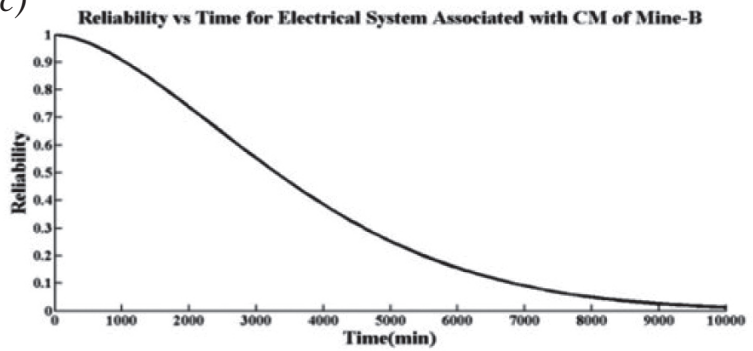

Rys. 3. Niezawodność podsystemów elektrycznych zasilajacych kombajny: CM-1 (a)

i CM-2 (b) z kopalni Mine-A

oraz kombajn z kopalni Mine-B (c) niezawodność w przypadku przenośnika odstawy głównej; osiągnięcie 50\% niezawodności w ciągu zaledwie 1500-1600 minut, a układ elektryczny i przenośnik kombajnu osiąga 50\% niezawodności kolejno po 4500-4600 i 7200-7300 minutach pracy. Podobne zależności zaobserwowano również w przypadku przenośnika odstawy głównej związanego z systemem w kopalni Mine-A z kombajnem oznaczonym CM-2, podczas gdy układ elektryczny tego kombajnu osiągnął 50\% niezawodności po 2000-2200 minutach pracy, a układ ładowania urobku osiągnął 50\% niezawodności po 7500-7700 minutach pracy. Przenośnik odstawy głównej systemu z kopalni Mine-B uzyskał lepszy wynik, osiągając 50\% niezawodności po 3500-3800 minutach pracy, w przypadku układu elektrycznego osiągnięcie 50\% niezawodności zajęło 3300-3500 minut, niezawodność wozów odstawczych osiągnęła 50\% po 6000-6500 minut pracy.

Wyniki analizy statystycznej kombajnu oznaczonego CM-2 i systemu z kopalni Mine-A i systemu oraz kombajnu z kopalni Mine-B przedstawiono w tabeli 3. Można zauważyć, że podsystemy hydrauliczne i przenośniki odstawy głównej w przypadku obydwu badanych kombajnów CM wykazywały znaczące różnice podczas pracy w danych warunkach.

Tabela 3

Wyniki testu istotności danych TBF (czas między awariami) w przypadku kombajnu CM-2 z kopalni Mine-A i kombajnu z kopalni Mine-B

\begin{tabular}{|c|c|c|c|c|c|}
\hline Nazwa podsystemu & Kombajn/ kopalnia & Średnia & Min. & Maks. & test Pearsona \\
\hline \multirow{2}{*}{ Zasilanie elektryczne } & CM-2 Mine-A & 2520,3 & 385,0 & 8585,0 & \multirow{2}{*}{ NS } \\
\hline & CM Mine-B & 3682,5 & 580,0 & 7200,0 & \\
\hline \multirow{2}{*}{ Głowica urabiająca } & CM-2 Mine-A & 27217,5 & 25995,0 & 28440,0 & \multirow{2}{*}{ NS } \\
\hline & CM Mine-B & 30240,0 & 30240,0 & 30240,0 & \\
\hline \multirow{2}{*}{ Ladowanie urobku } & CM-2 Mine-A & 6255,0 & 1285,0 & 19455,0 & \multirow{2}{*}{ NS } \\
\hline & CM Mine-B & 21840,0 & 480,0 & 43200,0 & \\
\hline \multirow{2}{*}{ Hydraulika } & CM-2 Mine-A & 5917,6 & 545,0 & 23645,0 & \multirow{2}{*}{$\mathrm{S}$} \\
\hline & CM Mine-B & 18267,5 & 13495,0 & 23040,0 & \\
\hline \multirow{2}{*}{ Podwozie } & CM-2 Mine-A & 18820,0 & 18820,0 & 18820,0 & \multirow{2}{*}{ NS } \\
\hline & CM Mine-B & 21600,0 & 21600,0 & 21600,0 & \\
\hline \multirow{2}{*}{ Wóz odstawczy } & CM-2 Mine-A & 3407,7 & 510,0 & 11735,0 & \multirow{2}{*}{ NS } \\
\hline & CM Mine-B & 7554,0 & 1880,0 & 20550,0 & \\
\hline \multirow{2}{*}{ Podajnik } & CM-2 Mine-A & 7150,0 & 4940,0 & 9360,0 & \multirow{2}{*}{ NS } \\
\hline & CM Mine-B & 8640,0 & 8640,0 & 8640,0 & \\
\hline \multirow{2}{*}{ Przenośnik } & CM-2 Mine-A & 1937,7 & 525,0 & 5400,0 & \multirow{2}{*}{$S$} \\
\hline & CM Mine-B & 3648,5 & 765,0 & 9265,0 & \\
\hline
\end{tabular}

$\mathrm{NS}=$ nieistotny $(>0,05), \mathrm{S}=$ istotny $(<0,05)$ 


\section{KONSERWACJA I PRZEGLADY KOMBAJNÓW TYPU CM ORAZ URZALZZEŃ POMOCNICZYCH}

Przeprowadzone badania wykazały znaczne zmniejszenie produktywności systemów eksploatacyjnych opartych na kombajnach typu CM z powodu przestojów sprzętu. Wymaga to ustalenia właściwego harmonogramu konserwacji profilaktycznej podsystemów o niskiej niezawodności w takich systemach. Konserwacja prewencyjna powinna być przeprowadzana przed następną prognozowaną awarią.

\subsection{Przenośnik odstawy głównej}

Przenośniki odstawy głównej muszą być sprawdzane codziennie co najmniej raz pod kątem jakichkolwiek nieprawidłowości.

Konserwacja prewencyjna obejmuje kontrolę rolek tocznych, bębnów napędowych i napinających, kontrolę hałasu silnika i przekładni zębatych oraz smarowanie wszystkich ruchomych części i łożysk zgodnie z wytycznymi producenta [11]. Należy opracować odpowiedni strategiczny program konserwacji wszystkich posiadanych przenośników.

\subsection{Kombajny chodnikowe urabiające liniowo}

Operatorzy powinni być zobligowani do sprawdzenia stanu maszyny przed rozpoczęciem i po zakończeniu jej pracy. Ogólna kontrola obejmuje sprawdzenie układów hydraulicznych, takich jak cylindry, pod kątem ewentualnych wycieków, sprawdzenie organu urabiającego pod względem wystąpienia nieprawidłowości (stan narzędzi urabiających), kontrola układu załadowczego i kontrola systemów sterowania [12-13].

\subsection{Systemy elektryczne}

Podczas badania stwierdzono, że istotny był także rodzaj awarii elektrycznej powodującej przerwanie zasilania w przypadku pracy maszyn systemu eksploatacyjnego. Ważna jest regularna kontrola stanu transformatora zasilającego, skrzynki aparatury elektrycznej i kabli zasilających. Przenoszenie kabla zasilającego kombajn podczas przejazdu wozów odstawczych powinno odbywać się z należytą starannością.

\section{WNIOSKI}

Niezawodność i dostępność sprzętu oznaczają niezawodność i produktywność całego systemu produkcyjnego. Analiza niezawodności systemów filarowo-komorowych stosowanych w Indiach w podziemnych zakładach górniczych i wykorzystujących kombajny typu CM wykazuje, że można spodziewać się w przyszłości znacznej poprawy funkcjonowania takich systemów, szczególnie wprowadzając nowe rozwiązania maszyn.

W niniejszej pracy dokonano analizy niezawodności i dostępności trzech kombajnów typu CM pracujących w dwóch kopalniach i zauważono, że program przeglądów i konserwacji tych maszyn i urządzeń pomocniczych musi być zaprojektowany w sposób strategiczny, aby zwiększyć ich wydajność i poprawić stosunek zwrotu z inwestycji. Wszystkie podsystemy systemów filarowo-komorowych wykorzystujących kombajny typu CM wymagają uwagi podczas ich kontroli i konserwacji. Jednakże niezawodność przenośników odstawy głównej kopalni i instalacji elektrycznej jest kluczowa dla zapewnienia niezawodności całego systemu i wymaga zdecydowanie większej uwagi w aspekcie ich przeglądów i konserwacji. Kryteria niezawodności można wykorzystać do zaprojektowania strategicznego harmonogramu przeglądów i konserwacji, aby zapobiec awariom, zwiększyć dyspozycyjność i produktywność newralgicznych podsystemów.

\section{PODSUMOWANIE}

Artykuł opisuje wpływ czynników geologicznych i przestojów systemu wykorzystującego kombajny typu CM na wydajność procesu podziemnej eksploatacji węgla. Określono dyspozycyjność różnych podsystemów wchodzących w skład systemów filarowo-komorowych wykorzystujących kombajny typu CM. Następnie zastosowano najkorzystniejsze rozkłady prawdopodobieństwa w celu określenia niezawodności trzech najbardziej awaryjnych podsystemów dla każdego z badanych systemów eksploatacyjnych. Zaproponowano opracowanie planu konserwacji i przeglądów w celu zwiększenia produktywności tych systemów. 


\section{Podziękowania}

Autor dziękuje urzędnikom Eastern Coalfields Limited za udzielenie zgody na badania i ich ciągłe wsparcie, a także profesorowi Inżynierii Górnictwa w IIEST, Shibpur w Indiach Netay C. Deyowi za jego cenne spostrzeżenia, sugestie i wsparcie.

\section{Literatura}

[1] Annual Coal Report 2016-17, Chapter 6, Ministry of Coal Government of India, http://coal.nic.in/sites/upload files/coal/files/coalupload/chap6AnnualReport1617en.pdf [14.07.2017].

[2] The Indian coal sector: Challenges and future outlook, Indian Chamber of Commerce, https://www.pwc.in/assets/pdfs/industries/power-mining/icc-coal-report.pdf [14.07.2017].

[3] Bridging the gap Increasing coal production and sector augmentation, Indian Chamber of Commerce, https:/www.pwc.in/ assets/pdfs/publications/2016/icc-pwc-coal-report-june.pdf [14.07.2017].

[4] Griffith E.D., Clarke A.W.: World coal production, „Scientific American" 1979, 240, 1: 38-47.

[5] World energy resources Coal 2016, World Energy Council, https://www.worldenergy.org/wpcontent/uploads/2017/03/ WEResources_Coal_2016.pdf [13.12.2017].

[6] Rahimdel M.J., Hosienie S.H., Ataei M., Khalokakaei R. The reliability and maintainability analysis of pneumatic system of rotary drilling machines, ,Journal of The Institution of Engineers (India): Series D” 2013, 94, 2: 105-111.
[7] Rohani H., Roosta A.K.: Calculating Total System Availability, Information Services Organization KLM-Air France, Amsterdam 2014.

[8] Vagenas N., Runciman N., Clément S.R.: A methodology for maintenance analysis of mining equipment, „International Journal of Surface Mining. Reclamation and Environment" 1997, 11: 33-40.

[9] Raghavan V., Ariff S., Kumar P.P.: Optimum Utilisation of Continuous Miner for Improving Production in Underground Coal Mines, „International Journal of Scientific and Research Publications" 2014, 4, 10: 374.

[10] Modi J., Bharti S., Kant R.: Applicability of Continuous Miner in Room and Pillar Mining System: Higher Production and Productivity with Safety, International Conference on Deep Excavation, Energy Resource and Production, Kharagpur 2017.

[11] Lubrication and maintenance check list, Automated Conveyor, INC, http://www.automatedconveyors.com/acrobat/maintenance_schedule.pdf [18.07.2017].

[12] De Clercq F.J.: Maintenance planning and optimal replacement of sub-assemblies for Continuous Miners, Published as a domain property of University of Pretoria, Pretoria 2009.

[13] Safety and Maintenance Checklist, Caterpilar, http://s7d2. scene7.com/is/content/Caterpillar/C10868548 [18.07.2017].

BANERJEE SUMIT

Department of Mining Engineering Indian Institute of Engineering Science and Technology, Shibpur Howrah - 711103, West Bengal, India sumit.banerjee92@yahoo.com 